\title{
The dynamics of international market withdrawal
}

Citation for published version (APA):

Pauwels, P. F. J., \& Matthyssens, P. (2002). The dynamics of international market withdrawal. METEOR, Maastricht University School of Business and Economics. METEOR Research Memorandum No. 038 https://doi.org/10.26481/umamet.2002038

Document status and date:

Published: 01/01/2002

DOI:

10.26481/umamet.2002038

Document Version:

Publisher's PDF, also known as Version of record

\section{Please check the document version of this publication:}

- A submitted manuscript is the version of the article upon submission and before peer-review. There can be important differences between the submitted version and the official published version of record.

People interested in the research are advised to contact the author for the final version of the publication, or visit the DOI to the publisher's website.

- The final author version and the galley proof are versions of the publication after peer review.

- The final published version features the final layout of the paper including the volume, issue and page numbers.

Link to publication

\footnotetext{
General rights rights.

- You may freely distribute the URL identifying the publication in the public portal. please follow below link for the End User Agreement:

www.umlib.nl/taverne-license

Take down policy

If you believe that this document breaches copyright please contact us at:

repository@maastrichtuniversity.nl

providing details and we will investigate your claim.
}

Copyright and moral rights for the publications made accessible in the public portal are retained by the authors and/or other copyright owners and it is a condition of accessing publications that users recognise and abide by the legal requirements associated with these

- Users may download and print one copy of any publication from the public portal for the purpose of private study or research.

- You may not further distribute the material or use it for any profit-making activity or commercial gain

If the publication is distributed under the terms of Article $25 \mathrm{fa}$ of the Dutch Copyright Act, indicated by the "Taverne" license above, 
FORTHCOMING IN:

Jain, Subhash. 2002. State of the Art of Research in International Marketing Edwar Elgar Publishing

\title{
The Dynamics of International Market Withdrawal
}

\author{
Pieter Pauwels* \\ MAASTRICHT UnIVERSITY, THE NETHERLANDS \\ Paul Matthyssens** \\ LIMBURG UNIVERSITY CENTER, BELGIUM \\ ERASMUS UNIVERSITY, THE NETHERLANDS
}

This study focuses on the decision-making process of international market withdrawal within the scope of international market portfolio management. A comparative study of eight withdrawal cases in four multinational firms results in a six-phased decision-making model that is driven by threat-rigidity behavior, failure-induced learning and political dynamics. Two types of international market withdrawal are identified. On the one hand, a tacticalal withdrawal is the outcome of threat-rigidity and exploitative learning at the level of executive management. A strategic withdrawal, on the other hand, is characterized by a process of failure-induced exploratory learning initiated by middle level challengers. In contrast to a tactical withdrawal, which remains an isolated decision and does not interfere with other international ventures of the business unit, a strategic withdrawal turns out to be a germ of strategic (re)orientation of the business unit's entire international market portfolio. Whether a market withdrawal turns out to be tactical or strategic ultimately depends on the autonomy, the amount and the relevance of challengers' market and business knowledge.

\footnotetext{
*Pieter Pauwels, Maastricht University, Faculty of Economics and Business Administration, Dept. of Marketing and Marketing Research, P.O.Box 616, 6200 MD Maastricht, The Netherlands, Phone: +31-43-388.37.74, Fax: +31-43-388.49.18, E-mail: p.pauwels@mw.unimaas.nl

**Paul Matthyssens, Limburgs Universitair Centrum, Fac. TEW, Universitaire Campus, B-3590 Diepenbeek, Belgium. Phone: +32-11-26.86.42, Fax: +32-11-26.87.00, E-mail: paul.matthyssens@luc.ac.be and Erasmus University, Department of Marketing, Faculty of Management, P.O. Box 1738, 3000 DR Rotterdam, The Netherlands.
} 


\section{INTRODUCTION}

A multinational firm regularly optimizes its international market portfolio through expansions, extensions and retractions. Given limited resources, changing market opportunities may require resetting priorities in the current portfolio, including the withdrawal of less promising ventures. However, market interconnectedness and other exit barriers may turn this exercise into a complex decision (Douglas and Craig 1995, 1996). This study focuses on international market withdrawal as a strategic instrument within the logic of international market portfolio management. International market withdrawal is defined as a firm's or business unit's decision to reduce its engagement in market-related activities in a foreign product/market combination

The obvious practical relevance of international market withdrawal (see for instance: Birkinshaw and Ritchie 1993; Calof and Beamish 1995; Benito 1997) stands in sharp contrast to the relative neglect in the literature. Most classic handbooks on international business and global marketing do not or hardly mention this phenomenon. Compared to an extensive industrial organization track on causes of exit and exit barriers (e.g., Harrigan, 1985) and work on divestment in organizational behavior (e.g., Duhaime and Schwenk, 1985), exit and divestment studies in international business are scarce. In the 1980s Jean Boddewyn studied foreign direct divestment, which was put forward as the reverse of FDI (e.g., Boddewyn, 1983). Later, Welch and Luostarinen (1988) conceptually developed the broader phenomenon of 'de-internationalization'. Only recently, Fletcher (2001) and Lamb and Liesch (2002), among others, presented promising endeavors to include and explain withdrawal in a (more dynamic) internationalization process theory. Except for Crick (2002) who focuses on the perceptions of why exporting is discontinued, empirical studies of causes, processes and outcomes of international market withdrawal have not been published yet.

The objective of this paper is to explore international market withdrawal within the decision-making unit and to understand the 'how' and 'why' of this phenomenon in the context of a particular internationalization process of a business unit. As such, we aim at unraveling the process of 
international market withdrawal and at understanding how this phenomenon fits in the overall internationalization of the firm. In the next section, the methodology of this study is presented. In the third section, the analytic outcome is discussed and summarized in a six-phased process model, comprising specific propositions for future validation. The final section summarizes the main drivers and dynamics of this process and identifies some managerial recommendations as well as specific leads for further research.

\section{Strategy Process Methodology}

Strategy process research involves a longitudinal investigation of a network of choices (strategic decision-making) and implementation processes (strategic change) enacted by managers (Pettigrew, 1992; Ferlie and McNulty, 1997). This approach has long been proposed as a key for a better understanding of the dynamics underlying the internationalization process (e.g., Melin, 1992; Andersen 1993). However, real process studies of internationalization remain scarce up until now. For this study, we zoom in on international market withdrawal, which is considered as an 'international episode' or "a dense cluster of activities which aims at a rapid change of the international fingerprint" (Kutschker et al., 1997 p. 105), in the context of the internationalization process of a firm.

The empirical focus is limited to an in-company analysis of antecedents, (sub-)processes - both decision-making and implementation - and consequences situated within an inner (e.g., the corporate strategy of the firm) and outer (e.g., local market dynamics) context of the decision to withdraw. The basic unit of analysis is the withdrawal process from an international product/market combination by a strategic business unit.

While the exploratory nature of this study requires theoretical sampling (Yin 1994), it turned out to be difficult to identify and select cases. Firstly, no existing database was found that could help us compose a sampling frame. Moreover, companies are not eager to reveal that they have recently withdrawn from a foreign market. As a consequence, we relied upon a convenience sample of twelve 
multinationals - all important pan-European or global players in various business-to-business industries - to compose a shortlist of 30 foreign product/market combinations that had been withdrawn by these multinationals within the last five years. Secondly, we applied three proxy criteria to select extreme or polar cases from this shortlist: (1) market entry strategy (active versus reactive), (2) the maximal profitability of the venture (low/middle/high), and (3) our subjective evaluation of the company's position on the EPRG continuum at the time of withdrawal (Perlmutter 1969). Through maximal variation on each of these dimensions, we aimed at polarity among the cases and, eventually, at a study with maximal internal validity (Yin 1994). This exercise resulted in ten cases from four companies. After a first interview, two cases of these cases were not selected, respectively due to the unavailability of some key respondents, and a misfit with our definition of international market withdrawal. Ultimately, eight cases were selected (Table 1).

\section{TABLE 1}

\section{Eight cases of international market withdrawal}

Data were collected mainly through in-depth interviews. We personally interviewed between two and five respondents per case once or twice. Respondents were selected on the basis of their role as pro- or antagonist in this particular episode. Typical respondents were general managers, international marketing managers, and area managers. Interviews lasted between one and a half and two and a half hours and topic lists were used to structure the interviews. After each interview, the transcript was sent to the interviewee for revision. By telephone, the respondent was asked to comment on this transcript and to clarify the points that could lead to misinterpretation. Additional data source triangulation was limited for two reasons. Firstly, strict confidentiality required by all business units did not allow us to contact relevant external respondents. Secondly, secondary data were not available because such documents did not exist (anymore) or because the companies were not eager to release them. In general, the negative connotation of a withdrawal made it extremely difficult to identify appropriate cases and to persuade managers to cooperate in a disclosing atmosphere. Eventually 41 interviewees 
were held and convergence of the data across the cases gave us a strong feeling of validity (Kvale 1996). The lack of convergence between some inferred patterns could be explained by existing theory.

Inferential Pattern Coding (IPC) was adopted as main analytic tool (Miles and Huberman, 1994; Yin, 1994). Equivalent to cluster and factor analytic devices in multivariate analysis, IPC (1) reduces large amounts of qualitative data into smaller numbers of analytic units or incidents, (2) helps elaborating maps (charts or matrices) for understanding incidents and (causal) interactions between abstracted events, and (3) enables cross-case analysis by identifying common themes and time-ordered displays (Miles and Huberman 1994). For the implementation of IPC, we largely followed the analytic process as described in Miles and Huberman (1994, pp.90-237), which consists of three analytical steps: (1) pattern coding, (2) drawing of within-case sequential incident networks, and (3) drawing of a causal network across cases. IPC was performed using QSR NUD*IST 4.0 (Sage Publication Software 1997), a Windows-based software tool for computer aided qualitative data analysis. This tool has been indicated as an appropriate device for pattern matching methodology on which IPC is based (Richards and Richards 1998). Although driven by elaborate case data, this study is not purely inductive. Throughout the analysis, the findings and interim conclusions were regularly challenged and compared with relevant studies in organizational behavior, strategic management and political science.

\section{UNRAVELING INTERNATIONAL MARKET WiTHDRAWAL}

This section describes critical incidents in the process of international market withdrawal as they were observed in and across the cases. These critical incidents are identified as the 'accelerators' in the inferred pattern, which, as a whole, comprises the strategy process of international market withdrawal. As such, these critical incidents cannot be considered in isolation. However, ex post and for the sake of comprehensibility, the entire pattern was divided in six phases, chronologically organized around the six most important 'accelerators'. From these findings, initial assumptions are made about the drivers, conditions and direction of the decision-making process. Later in the process, specific propositions are 
formulated. Both the assumptions and the propositions are critically assessed and related to theories and studies in the extant literature.

During the analysis, two cases emerged as atypical: Eta-Germany and Sigma-Brunei. For explainable reasons, these two cases behave differently in some or many of the phases. Although Eta-Germany fits in with our definition, it soon became clear that this case was just part of a major product range contraction. Case Sigma-Brunei shares many characteristics with the other cases, except for one. This venture was set up as a project venture. From the start, management knew that sooner or later it had to be broken up. This built-in deadline - and the lack of deadlines in the other cases - provides us with significant findings for comparison and discussion. Although limited space prevents us from explicitly discussing these two cases here, they offered interesting points of reference for comparing fundamentally different strategy change processes (Yin 1994).

\section{Phase 1: Accumulating Commitment}

At a certain moment in their history and before the withdrawal was decided upon, all ventures were of strategic importance to the business unit and held an important place in their respective international market portfolios. In some of the cases, organizational commitment increased gradually over the years: additional personnel were hired, more financial resources were invested, the venture obtained a higher priority position for future investments, etc. In other cases, commitment increased more dramatically due to particular events or decisions. Quoting some respondents illustrates this increasing commitment:

\footnotetext{
"First, the cowboys came out and screened the market and its opportunities in a very flexible and fast way. When additional investments were required to grab the market, it became important to get [the venture] under control." (Area Manager, Lambda-Russia)

"Over the years, our engineering activity in the UK grew steadily and large investments were made in design software." (Former Group President, Sigma-UK)
}

In all cases, this strategic position results in increased institutionalization of the venture and its accompanying strategy in the business unit's international market portfolio. Local marketing and organizational structures are brought in line with the international marketing strategy and control 
instruments are installed. Although not a causal factor of withdrawal in itself, institutionalization turns out to be a highly relevant constraint to the withdrawal decision-making later on in the process. Institutionalization is a homeostatic process, i.e., a self-supporting process that forces an organization to increase internal stability and the reliability of their decision-making. As such, the strategic logic, which had been adopted initially, has become the dominant logic. Confirming and further embedding this dominant logic is the prime goal of a homeostatic process (Huff, Huff and Thomas 1992; Haveman 1993).

This assumption of institutionalization is also relevant to distinguish the phenomenon of this study from what Welch and Wiedersheim-Paul (1980) label 'export failure' or 'missed export start'. These authors suggest that withdrawal is most likely to occur only during the earliest stages of internationalization. They argue that a lack of market knowledge and resources are constraining factors only in the first stages (Johanson and Vahlne 1990). As a consequence, it can be expected that internal intangible exit barriers are much lower in the case of a 'missed export start' compared to the withdrawal process under investigation here.

\section{Phase 2: Increasing Stress}

Under stable environmental conditions, institutionalization enhances performance through efficiency (Nelson and Winter 1982). In none of the eight cases, though, performance materialized as expected. This performance gap was the prime, and in most cases the first, indicator of an increasing misfit between the strategic orientation of the business unit in this venture and unexpected market dynamics.

The effect of this misfit, i.e., the discrepancy between the level of aspiration and the perceived level of achievement is labeled stress (Huff, Huff and Thomas 1992; Ocasio 1995). Stress induces agents to search for causes and solutions to reduce the stress level (Huff and Clark 1978). In the observed ventures, however, management could not easily identify what caused performance to decrease. In all cases, causal ambiguity was high (Reed and DeFilippi 1990). Due to this ambiguity, individuals - in- 
and outside the executive business unit management team - begin to develop their personal explanations of the causes of this poor performance. Initially, a lot of different interpretations emerge.

Soon, however, these interpretations converge to form two fundamentally different perspectives. In the first perspective, unsatisfactory performance is alleged to be the result of poor implementation of the current marketing strategy. As a consequence, resolving the problem seems feasible within the scope of the current strategic approach and "try harder" is the proposed key to success. As such, adherents of this perspective experience endogenous stress (Dutton and Duncan 1987; Barr, Stimpert and Huff 1992). Stress is labeled endogenous when failure is perceived to be due to a misfit between the strategy and its implementation. The following quote illustrates this perspective:

\footnotetext{
"They perceived the fundamental instability of the market as a temporally higher degree of difficulty and not as critical. [...] At that time, the business divisions' dictum was to try harder and certainly not to give up their autonomy." (Lambda-Russia, Area Director)
}

In the second emerging perspective, unsatisfactory performance is alleged to be the result of the increasing inappropriateness of the current strategic status quo itself. As a consequence, the proposed solution to the incurred problems lies outside the operational scope of this particular venture's current marketing strategy. In contrast to the 'try harder' solution, the advocates of this perspective do not perceive enough maneuverability within the present strategic approach. To reduce stress, the strategic status quo has to be altered. As such, the protagonists of the second perspective experience exogenous stress (Dutton and Duncan 1987; Barr, Stimpert and Huff 1992). Stress is labeled exogenous when failure is perceived to be due to a misfit between the venture's marketing strategy and the changing business environment. The following quote is illustrative: "We had gone too far. The market was there but we had approached it in the wrong way." (Kappa -Spain,
Marketing and Sales Manager)

Whereas most interviewees reported both endogenous and exogenous stress, in-depth analysis clearly illustrates that every agent acted upon the logic of one predominant type of stress. Moreover, personal predispositions remain fairly stable throughout the decision-making process. It was observed further that managers with inward-oriented tasks and high hierarchical power in the venture express 
endogenous stress. Managers that are more remote from the venture's decision center and perform more boundary-spanning activities express exogenous stress. Therefore, the following propositions are set:

$P_{1 \mathrm{a}}$ : The higher the hierarchical power and the more inward-oriented the task of an agent within a failing venture, the more $\mathrm{s} / \mathrm{he}$ experiences and acts upon endogenous stress.

$P_{1 b}$ : The more remote the agent is from the decision center and the more boundaryspanning the task of this agent within a failing venture, the more $s /$ he experiences and acts upon exogenous stress.

The consequence of these propositions is that agents with high hierarchical power and with an inwardoriented function will stick to the current local marketing strategy in trying to redress the venture. Agents more remote from the decision center with boundary-spanning functions are expected to reject the current local marketing strategy and are expected to go for a new strategic approach.

Ample support is found for these findings. Johnson (1988) argues that scattered visions on problems tend to converge to form a limited set of conflicting perspectives. Others, such as Dutton and Duncan (1987), Barr, Stimpert and Huff (1992), and Tushman and Romanelli (1985) develop the notions of endogenous and exogenous stress. If people's frame of reference fits in with the dominant logic of the organization, stress is expected to be endogenous. As such, environmental signals are interpreted as consonant with the individual mental models as well as with the dominant logic. When an agent predominantly experiences exogenous stress, the individual mental models on this issue are dissonant with, and overrule the dominant logic of the organization (Johnson 1988). Evidently, attention of managers is likely to be allocated to information that is easily interpreted within and that supports the current frame of reference of the individual (Kuwada 1998). This individual frame of reference focuses attention on data that are compatible with the framework and restricts attention to all others (Ocasio 1995). Environmental signals may be consonant or dissonant with the agent's current frame of reference (Johnson 1988). Events that refute the present frame of reference may be disregarded or interpreted within the scope of that frame. 


\title{
Phase 3: Conflicting Reactions to Increasing Stress
}

Stress induces reaction to reduce it. The business units initially react in a tactical way, thereby trying to improve the implementation of the current strategic approach - the 'trying harder' solution - as is illustrated by this quote:

\begin{abstract}
"In 1992, I went over every week. The Belgian subsidiary incurred heavy losses. However, bringing in management capacity reversed the situation within a year. [...] When we decided to release it again, losses increased instantly. This indicated that management capacity was too low. [...] After we had dismissed the Dutch manager, we did not want to engage a new man. The sales staff would not have accepted someone new. They were convinced of the fact that they could handle the problems and reverse the situation themselves. Accordingly, we decided to install [the sales staff as] a two-headed management team. [...] Again, a year was lost. In 1994, we decided to discharge one of the managers and we appointed the more reliable of the two as managing director of the Belgian subsidiary. At the same time, however, we decided to close the place down. [...] The newly appointed director argued that this was an unfair decision; he had not had the chance to prove himself. [...] So we decided to continue for one more year." (Kappa-Belgium - Sales and Marketing Manager)
\end{abstract}

This observation of inertial, tactical and reactive behavior is made comparably across all cases. Indeed, executive business unit managers themselves are the authors of the current marketing strategy of this particular international venture. They will stick to this strategy and follow standard routines within the scope of it to redress the failing venture. Building upon this observation and proposition 1a, we propose:

\section{$P_{2 \mathrm{a}}$ : $\quad$ To redress a failing venture, a business unit's executive management adopts tactical routine measures that remain within the scope of the venture's current marketing strategy.}

Studies on organizational failure support this observation. For instance, Hambrick and D'Aveni (1988), and Barker and Duhaime (1997) reported on failing firms that initially responded to decline with increased tactical efforts to improve the implementation of the existing strategies. Indeed, the institutionalization of the venture has provided its executive management with some degree of maneuverability and an accompanying range of pre-established tactical measures. Building upon endogenous stress, executive management disregards information that may challenge the current strategic logic and further strengthens institutionalization through the implementation of these tactical measures. Combining propositions 1a and 2a implies that decreasing performance induces tactical, reactive and inertial organizational behavior, which strengthens the current strategic status quo. This 
conclusion is in line with threat-rigidity and organizational inertia theory (Amburgey, Kelly and Barnett 1993; Ocasio 1995).

However, soon after the first tactical measures had been implemented, challengers emerged around the experience of exogenous stress. Initially, these challengers informally rejected the current tactical measures as a valuable cure for the failing venture. Typically, challengers are middle-level players in marketing, sales, area, and project management. Their opinion feeds on continuing poor performance, remaining causal ambiguity and, in particular, on their relatively high degree of knowledge autonomy. In line with the literature, the cases confirm that the challengers' knowledge autonomy is relatively high because: (1) they are new to the organization and have no prior commitment to the current logic (Kappa-Spain; Tushman, Newman and Romanelli 1986), (2) they are involved in boundary-spanning activities (Lambda-Turkey and Lambda-Russia; Hutt, Reingen and Ronchetto 1988), and/or (3) they are operating in the foreign subsidiary itself. As such, these challengers experience (divisional) independence and have access to additional market-specific information (Kappa-Belgium, Eta-Japan and Sigma-UK; Ghertman 1988; and Hitt, Keats and Demarie 1998).

In some cases, the challengers go beyond informal rejection of the tactical measures, in some of the other cases they do not. As such, two types of reaction are observed: passive and pro-active rejection (Table 2).

\section{TABLE 2}

\section{Two Types of Reaction to Tactical Routine Measures}

Although the tactical measures are informally rejected in Type1-cases, no challenger is able to launch and defend an alternative strategic proposal. In Type2-cases, to the contrary, challengers propose and develop an alternative strategic option. From the comparative analysis of both types, it is argued that 
the difference between passive rejection and pro-active rejection accrues from the level and relevance of market and business knowledge of the challengers. A quote may illustrate this:

\begin{abstract}
"The real centers of power are in Paris, Stuttgart and Antwerp. However, this venture did not receive the strategic drive we would have expected. [...] I had the luck to be there when it all happened. I had hands on when the crisis emerged and saw how our competitors reacted. [...] In this case, I may conclude that this decision was taken locally and 'sold' to top management." (Lambda-Turkey, Area Director MSOD)
\end{abstract}

Building upon previous propositions and these observations, we state the following propositions:

\title{
$P_{2 b}$ : Tactical routine measures in reaction to decreasing performance induce rejection of these measures and of the current strategic logic altogether. \\ $P_{2 \mathrm{c}}$ : Rejection of tactical routine measures in reaction to decreasing performance induces the creation of alterative strategic options if (1) sufficient, and (2) relevant market and business knowledge is (3) autonomously available in the venture's organization.
}

Support for this proposition is found in Doz and Prahalad (1987) and Burgelman (1996), who argue that lower managers may become aware of the need for strategic redirection. However, they may lack access, influence, data, and, as a consequence, receptive ears to develop and push alternative ideas. We argue that this is the case in the 'passive rejection' type. Alternatively, in the 'pro-active rejection' type, the challengers have acquired relevant knowledge, which provides them with an alternative logic for the development of a non-routine solution (Dutton and Duncan 1987; and Hutt, Reingen and Rochetto 1988). Related to the literature on organizational learning, it is argued that the hierarchical power of the executive management induces exploitative learning within the frame of the dominant logic, whereas the knowledge power of the challengers induces exploratory learning by middle level challengers (March 1991).

\section{Phase 4: Power Play towards the Stress Threshold}

Despite an ongoing 'try harder' approach and many tactical measures, performance continues to decrease. Nevertheless, executive management does not give up its commitment towards the current logic and the accompanying cures, to the contrary:

\footnotetext{
"The objective remained a foreign subsidiary which was able to walk on its own. It is not acceptable that we [executive management] have to be involved in managing it on a day-to-day basis. However, as soon as we had left, profitability dropped again. And this went on for many months.” (Kappa-Belgium, Executive Management)
} 
In Type1-cases ('passive rejection'), current tactical cures continue to be questioned by some middle level managers. However, rejection fades out, as it does not take root in the organization due to a lack of a strategic alternative, a prerequisite for organizational support. As a consequence, executive management of Type1-cases continues with increasingly ineffective tactical cures until the venture reaches rock bottom.

In Type2-cases ('pro-active rejection'), increasing stress and poor performance strengthen the creative efforts of knowledgeable and independent challengers. Indeed, in all of the observed Type2-cases, challengers develop and experiment with a new strategic logic that, in all cases, goes beyond fighting the problems of the failing venture. Indeed, they start their exercise by (re)setting priorities in the international market portfolio of business unit. Priority criteria are (re)defined, strategic goals on the short and long term are (re)set and the current international market portfolio is benchmarked against these new priorities, taking into account barriers of maneuverability within the portfolio. In all cases of this study, withdrawal of this particular venture is a logical consequence of strategic reorientation though, evidently not, a necessary ingredient of every strategic alternative for a failing foreign venture outside our sample. In sum, the challengers' strategic alternative is formulated at the level of the entire foreign market portfolio. It has the portfolio and not the failing venture as its main focus.

Furthermore, the challengers seek and find informal support at higher echelons of the organization, i.e., beyond the executive management of this business unit. Doing so, they try to back up their increasing knowledge power with hierarchical power. As soon as the hierarchical power of the challengers increases to a certain level, authority over the venture switches from the executive management to the challengers. In some cases this transition occurs smoothly. In others, it is more dramatic including lay offs and a formal repositioning of executive managers. Quotes from the Lambda cases illustrate the relationship between challengers, the executive management and higher echelons in this phase:

\footnotetext{
"This $[\ldots]$ brought about strong reactions, especially from the business directors. They accused me of being a defeatist. [...]. When this vision got accepted at HQ level, I had the business director against me. They simply did not want to accept the situation." (Lambda-Russia, Area Director MSOD)
} 


\footnotetext{
"Another key factor is my good relationship with the director of International Operations. He is mature enough to cope with bad news. He does not panic. The thrust that existed between subsidiary and headquarters acted as a differentiator." (Lambda-Turkey, Area Director MSOD)
}

The extant literature underpins this dramatic evolution. Escalating commitment instructed by current executive management fits within treat-rigidity theory (e.g., Staw, Sandelands and Dutton 1981; Ocasio 1995), which argues that continuing adversity increasingly leads to a restraint of information processing, constriction of control, and increased rigidity in organizational behavior. In contrast to the rigid behavior of the executive management, the challengers are increasingly committed to the creation and adoption of a strategic alternative. Due to the ongoing search for information beyond the dominant logic and the increasing commitment to higher order exploratory learning, causal ambiguity decreases and exogenous stress increases dramatically (Johnson 1988; and Huff, Huff and Thomas 1994). The 'real' troubling facts become clear to an increasing number of members of and beyond the business unit (Aharoni 1966). Combining the reactive threat-rigidity behavior of executive management with pro-active failure-induced learning of the challenging coalition, we claim that, as commitment to the conflicting learning paths continues to increase, both endogenous stress and exogenous increase until a threshold is reached (Schwenk 1989; and Ocasio 1995).

Whereas no hierarchical power shift occurs in Type1-cases, in Type2-cases the power base shifts away from executive management towards the challengers. Indeed, over different phases of the withdrawal process, we observed an increasingly important underlying political process between the proponents of two strategic logics, which Huff, Huff and Thomas (1992) label as a dialectic between accumulating exogenous stress and accumulating inertia within the framework of the dominant logic. However, at a certain moment both endogenous and exogenous stress are at their maximum and the venture reaches rock bottom. Barr, Stimpert and Huff (1992, p. 19) define this threshold as the point where "the level of [exogenous] stress (the level of pressure to change) exceeds the level of inertia (the level of pressure to maintain)". The Type2-cases suggest that the impact of reaching a threshold may be extreme, depending on the preceding process. The consequences of reaching the threshold are discussed in the following section. 


\section{Phase 5: A Fait Accompli in Type2-cases}

Phase 5 is operationally defined as the episode that starts at the stress threshold, i.e., where both endogenous and exogenous stress are maximal and the venture reaches rock bottom, and is ended with the formal decision to withdraw. Although in most Type2-cases (e.g., Lambda-Turkey and LambdaRussia) this phase took less than a couple of hours, in others - mostly Type1-cases - the time gap between maximum stress and the formal decision to withdraw was considerable (e.g., in Sigma-UK up to 15 years). Since the difference between Type1- and Type2-cases culminates in this phase, we discuss them under separate headings.

In Type2-cases ('pro-active rejection'), the challengers have now gained hierarchical power over the problematic venture and in most cases even over the entire international market portfolio of this business unit. The first initiative concerning this venture is to isolate and de-institutionalize it from the rest of the international market portfolio. In all cases, the new leaders at least assess whether the venture is sufficiently isolated before the withdrawal can be implemented. Two quotes illustrate this:

\footnotetext{
"Moreover, you could say we had to stay in Japan to cover other countries in the region. However, this is not correct. Japan is really isolated." (Eta-Japan, Regional Export Manager)

"You know, Brunei was a small market, which operated independently from other operations. All engineering was performed locally.” (Sigma-Brunei, Project Engineer Manager)
}

Secondly, the venture's resources are reallocated to a new strategic goal: a new product/marketcombination (Eta-Japan), a new entry strategy (Kappa-Spain), a new strategic thrust (LambdaTurkey), or a new organizational set up for growth (Lambda-Russia). As this reallocation builds upon earlier experimentation by the old challengers, the formal decision lags behind reality:

\footnotetext{
"I think that decisions of this kind are taken in the field. [...]. All major decisions are taken in this way. [...] From a certain moment on, it is 'sold' to the top. However, if you have someone who strongly defends the idea, they will accept in all cases." (Lambda-Turkey, Area Director MSOD)

"The implementation is a fait accompli. [...] In fact, we do not even bring a detailed strategy to [the top management] but a vision." (Lambda-Russia, Area Director MSOD)
} 
As such, the withdrawal is more a consequence or 'fait accompli' than a decision on its own. Moreover, interviewees of Type2-cases affirm that top management would not have accepted any of these withdrawals if they had not been the logical consequence of a larger-scale strategic reorientation, which accommodates a strategic alternative for this venture. Therefore, it is proposed that:

\section{$P_{3 a}:$ In disregard of a failing venture's history and performance, withdrawal of a venture is not a real option if the venture cannot be isolated from the rest of portfolio and if no accepted strategic alternative is available for the freed resources.}

The literature emphasizes the importance of decoupling ventures (Douglas and Craig 1995), though suggests that de-institutionalization may not be problematic if: (1) a strategic alternative for the freed resources is available, (2) the venture is isolated from the current strategic context of the venture, and (3) causal ambiguity is low (Simonson and Staw 1992; Ross and Staw 1993; and Drummond 1995). Secondly, in many organizational change models the decision to adopt a new strategic direction is separated (in time) from the decision to leave the old strategic logic (e.g., Tushman and Romanelli 1985). Indeed, Narayanan and Fahey (1982), and Hutt, Reingen and Ronchetto (1988) argue that commitment to a strategic alternative begins to evolve during the early stages of decision making rather than after the formal decision to reallocate is made. If the challenging vision is in conflict with the status quo (Type2-cases), challengers do not wait for formal approval before implementing their project (Howell and Higgins 1990). As a consequence, the formal decision merely brings the official strategy in line with the real activities and current practices are formally routinized (Burgelman 1996). A new round of institutionalization starts here.

\section{Phase 5: A Vacuum in Type1-cases}

When the stress threshold is reached in Type1-cases, executive management reaches the point at which it understands that none of the tactical measures have been effective. As a consequence, organizational commitment to the ventures decreases dramatically and the ventures soon become isolated from the rest of the international market portfolio:

"It is my experience that top management's interference decreases as things really begin to get worse. The message is: please continue trying hard, but don't bother us anymore. [...] The time top management devoted to these two ventures can be expressed in minutes, not in hours." (Lambda-Russia, Area Director MSOD) 
However, since no strategic alternative for the venture's resources is available, the decision to withdraw is not taken and/or approved of by top management. After all, the tactical measures that had been taken had increased the institutionalization of the venture and had resulted in a context - "we just have invested such an amount of money to redress this venture" (executive management Lambda-UK) - in which market withdrawal could not be a viable alternative. Both in Kappa-Belgium and in Lambda-UK, management's interest in the venture decreased rapidly. However, instead of withdrawing the venture, we observed that commitment began to escalate at the operational level of the venture, i.e., at the level of local non-challenging middle and lower managers. The overall driver changes from 'try harder' to 'save our souls'. The following quote illustrate this:

\footnotetext{
"During that period, we worked in a highly uncontrolled way and we hardly communicated with headquarters. There was no explicit strategy about how to redress the situation. If we communicated, it was about operational facts. So we made a plan ourselves. However, thinking about it now, we may have made major errors at the time.” (Kappa-Belgium, Sales Executive)
}

In fact, a vacuum is created when executive management starts to detach itself from the venture without withdrawing it. In this vacuum, strategic control decreases instantly. The cases suggest that this vacuum may continue to exist for a long time - in Sigma-UK for more than 15 years. Ultimately, an externally caused dramatic event such as a major accident or the bankruptcy of a customer is necessary to wake up executive management once more and makes them to decide to exit after all, using this incident as an excuse.

\section{$P_{3 b}$ : When a failing venture needs to be withdrawn, though the conditions of $P_{3 a}$ are not fulfilled, the venture comes into a state of strategic drift.}

This observed process of increasing detachment towards strategic drift is comparable to what Ross and Staw (1993) and Burgelman (1996) describe as 'organizational de-commitment'. As economic adversity, causal ambiguity and a stream of negative information continue to increase the organization turns its head towards more promising challenges, leaving the venture to its fate. Aharoni (1966), Johnson (1988), and Drummond (1994; 1995) support our finding that a venture comes into a vacuum when no alternative real option is available at the stress threshold. Within this vacuum, local commitment begins to escalate and the venture enters a state of strategic drift. Inertial behavior and 
creeping rationality emanating from the dominant logic, turns into escalating commitment and strategic drift when the venture is isolated and no organizational control remains over the activities in the venture (Bowen 1987; Ross and Staw 1993). Finally, the literature suggests that an external triggering event, which has disproportionate and symbolic influence, is required to break out of this vacuum. In fact, it does not directly cause withdrawal. It only provides the last straw for top management and an excuse for business unit management to decide on the withdrawal (Gersick 1991; Huff, Huff and Thomas 1992; 1994).

In sum, extreme stress - endogenous in Type 1 and exogenous in Type 2 - about an increasingly deinstitutionalized venture results in extreme strategic instability. However, this strategic instability is of a fundamentally different nature in Type1-cases compared to Type2-cases. In the former, venture performance reaches rock bottom and endogenous stress as well as causal ambiguity did not decrease despite increasing efforts to redress the situation. To the contrary, in the latter, a challenging logic gains momentum in the organization, causal ambiguity decreases, and a strategic alternative gains hierarchical power. Therefore, we formally distinguish between Type1- and Type2-withdrawal, which we respectively call tactical and strategic withdrawal. Both phenomena are more specifically defined in the following section.

\section{Phase 6: Beyond the Withdrawal}

In case of a tactical withdrawal (Kappa-Belgium, Sigma-UK, and Eta-Japan to a lesser extent), exploitative learning results in the unsuccessful adoption of all available routine and tactical measures. Ultimately, the organization detaches itself from the venture, not knowing what to do about the situation, and releasing strategic control. As a consequence, a painful de-institutionalization occurs through an uncontrolled process of local escalation of commitment. A tactical withdrawal is an extreme measure, which is decided upon in order to cope with strategic drift without understanding the real reason for the failure. 
In case of a strategic withdrawal (Lambda-Turkey, Lambda-Russia, and Eta-Japan to a lesser extent), exploratory learning results in a strategic alternative that replaces the old dominant logic. Moreover, this strategic alternative creates a strategic context that is needed for the withdrawal (see proposition $\mathrm{P}_{3 \mathrm{a}}$ ). In contrast to a tactical withdrawal, causal ambiguity and stress decrease dramatically as soon as the venture is withdrawn and the strategic alternative is adopted. A strategic withdrawal is decided upon as an evident measure within the framework of strategic reorientation, which is required to cope with environmental dynamics.

The cases illustrate that the stress threshold marks the beginning of an episode of instability that continues beyond the formal decision to withdrawal. In the case of strategic withdrawal, this new logic allows for strategic flexibility and higher order learning beyond the scope of the original failing venture. The cases illustrate that a strategic withdrawal of one particular venture is a germ for additional strategic reorientation at the level of the international market portfolio, or even at the level of the internationalization of the firms. In the words of an interviewee:

"We have used this crisis as a leverage to push our strategic vision." (Lambda-Russia, Area Director MSOD)

In sum, we propose:

\section{$P_{4 a}$ : Strategic withdrawal of a failing international venture is the germ of strategic reorientation in the entire international market portfolio.}

Support for this 'germ'-idea is found in the literature. Gersick (1991) and Burgelman (1996) describe dramatic corporate strategic reorientations, which had been initiated by a strategic reorientation at a lower level. Aharoni (1966), Burgelman (1996) and Kuwada (1998) argue that firms who have strategically exited from a business are likely to have a better understanding of the links between their distinctive competences and the basis of competition in the industry or market. In the case of tactical withdrawal, the ventures are stigmatized, as a failure and causal ambiguity remains high. Due to organizational de-commitment hardly any learning effect was observed after a tactical withdrawal. In fact, tactical withdrawal is a reaction to strategic drift, not to the real underlying problems of the failing venture. 
Four years after Kappa-Belgium had been withdrawn, an analysis of the present international market portfolio of Kappa suggests that this withdrawal had hardly influenced the overall international marketing strategy of the firm, to the contrary. At least three other subsidiaries in Eastern Europe were found that do not fit into the current global marketing perspective of the firm and, as a consequence, may need to be revised or withdrawn. Hence:

\section{$P_{4 b}$ : Tactical withdrawal of a failing venture prevents learning and strategic change within and beyond this venture.}

\section{CONCLUSION}

This comparative case study on the dynamics of international market withdrawal results in a sixphased process model, which is summarized in Figure 1. The model captures the entire withdrawal episode that starts with the perception of decreasing performance of an institutionalized venture and extends up to the consequences of this withdrawal on the business unit's international market portfolio. Critical underlying generative mechanisms are threat-rigidity and failure-induced learning, which, on their turn, are driven respectively by endogenous and exogenous stress. Equally important are political forces that exist between these to mechanisms. While more traditional models (e.g., the Uppsala Model) of internationalization are driven by a fairly narrow conception of learning (Forsgren 2002), this study illustrates how different types of learning (exploratory versus exploitative) jointly generate progression in the internationalization process. A further extension of this dual perspective is promising to extend our understanding of the dynamics in the internationalization process of the firm.

\section{FIGURE 1}

\section{A Process Model of International Market Withdrawal}

Nevertheless, this study remains an exploratory and intermediate step towards the explanation of international market withdrawal and the integration of this phenomenon in internationalization process theory. Several limitations are acknowledged. Although the utmost was done to strive for a sound 
theoretical sample, more (polar) cases should be investigated and more effort should be done in controlling industry, corporate and market parameters. More conceptual work is necessary to explain how these two conflicting drivers (exploratory versus explanatory learning) can co-exist and how a dialectical process is able to organize their co-existence. In this respect, important added value is expected from a comparative study with more formally developed models of organizational and strategic change. Finally, important work is still to be done in translating the central constructs and drivers of this model into measurable interrelated variables that are necessary for empirical testing.

Some important managerial lessons can be drawn. Firstly, it is striking that none of the observed business units had contingency plans that included withdrawal as a real option when certain deadlines were not met. In fact, no financial or time deadlines were set in any of the original strategic plans. Maneuverability within the original strategic plans was not based upon explicit tactical recipes but on unwritten, though deeply rooted, reaction styles. Furthermore, it is interesting to notice the importance of political dynamics. Although power play is a well-known sine qua non of organizations, too often managers and academics alike forget about the impact of it on important decisions. Understanding the intricacy of power plays is a critical factor in controlling decision-making processes. Finally, exploration and knowledge created at the boundary-spanning middle-level of the organization plays a crucial and positive role in the progression of the internationalization process. Top management should understand and safeguard the leverage this knowledge can create through stimulating bottomup communication and lower level experimentation. It is our belief that an organization's necessary 'strategic flexibility' has its roots in this bottom-up generative mechanism. 


\section{REFERENCES}

Aharoni, Yair. 1966. The Foreign Investment Decision Process. Boston, MASS: Harvard University.

Amburgey, Terry L., D. Kelly and W.P. Barnett. 1993. "Resetting the Clock: The Dynamics of Organizational Change and Failure." Administrative Science Quarterly Vol.38: 51-73.

Andersen, Otto. 1993. "On the Internationalisation Process of Firms: A Critical Analysis." Journal of International Business Studies Vol.24(2): 209-231.

Barker III, Vincent L. and I.M. Duhaime. 1997. "Strategic Change in the Turnaround Process: Theory and Empirical Evidence." Strategic Management Journal Vol.18: 13-38.

Barr, Pamela S., J.L. Stimpert, and A.S. Huff. 1992. "Cognitive Change, Strategic Action, and Organizational Renewal." Strategic Management Journal Vol.13: 15-36.

Benito, G.R.G. 1997. "Divestment of Foreign Production Operations.” Applied Economics, 29, 13651377.

Birkinshaw, Julian and W. Ritchie. 1993. "Balancing the Global Portfolio." Business Quarterly (Summer): 40-49.

Boddewyn, Jean J. 1983. "Foreign Direct Divestment Theory: Is It the Reverse of FDI Theory?" Weltwirtschaftliches Archiv Vol.119(2): 345-355.

Bowen, Michael G. 1987. "The Escalation Phenomenon Reconsidered: Decision Dilemmas or Decision Errors?" Academy of Management Review Vol.12(1): 52-66.

Burgelman, Robert A. 1996. "A Process Model of Strategic Business Exit: Implications for an Evolutionary Perspective on Strategy.” Strategic Management Journal Vol.17: 193-214.

Calof, J.L. \& Beamisch, P.W. 1995. Adapting to Foreign Markets: Explaining Internationalization. International Business Review, 4(2), 115-131.

Crick, Dave. 2002. "The Decision to Discontinue Exporting: SMEs in Two U.K. Trade Sectors." Journal of Small Business Management. Vol.40(1): 66-77.

Douglas, Susan P. and C.S. Craig. 1995. Global Marketing Strategy. New York: McGraw-Hill.

Douglas, Susan P. and C.S. Craig. 1996. "Executive Insights: Global Portfolio Planning and Market Interconnecteness." Journal of International Marketing Vol.4(1): 93-110.

Doz, Yves L. and C.K. Prahalad. 1987. "A Process Model of Strategic Redirection in Large Complex Firms: The Case of Multinational Corporations." In: Andrew M. Pettigrew (Ed.) The Management of Strategic Change. Basil Blackwell: 63-83.

Drummond, Helga. 1994. "Escalation in Organizational Decision Making: A Case of Recruiting an Incompetent Employee." Journal of Behavioral Decision Making Vol.7: 43-55.

Drummond, Helga. 1995. "De-escalation in Decision Making: A Case of a Disastrous Partnership." Journal of Management Studies Vol.32(3): 265-281.

Duhaime, Irene M. and C.R. Schwenk. 1985. "Conjectures on Cognitive Simplification in Acquisition and Divestment Decision Making.” Academy of Management Review Vol.10(2): 287-295. 
Dutton, Jane E. and R.B. Duncan. 1987. "The Creation of Momentum for Change Through the Process of Strategic Issue Diagnosis.” Strategic Management Journal Vol.8: 279-295.

Ferlie, Ewan and T. McNulty. 1997. " "Going to Market": Changing Patterns in the Organisation and Character of Process Research." Scandinavian Journal of Management Vol.13(4): 367-387.

Fletcher, Richard. 2001. "A Holistic Approach to Internationalization" International Business Review Vol.10: 25-49.

Forsgren, Mats. 2002. "The Concept of Learning in the Uppsala Internationalization Process Model: A Critical Review." International Business Review Vol.11: 257-277.

Gersick, Connie J.G. 1991. "Revolutionary Change Theories: A Multilevel Exploration of the Punctuated Equilibrium Paradigm.” Academy of Management Review Vol.16(1): 10-36.

Ghertman, Michel. 1988. Foreign Subsidiary and Parents' Roles During Strategic Investment and Divestment Decisions. Journal of International Business Studies Vol.19(1) (Spring): 47-67.

Hambrick, Donald C. and R.A. D'Aveni. 1988. "Large Corporate Failures as Downward Spirals." Administrative Science Quarterly Vol.33: 1-23.

Harrigan, Kathryn R. 1985. "Exit Barriers and Vertical Integration." Academy of Management Journal Vol.28(3): 686-697.

Haveman, Heather A. 1993. "Organizational Size and Change: Diversification in the Savings and Loan Industry after Deregulation.” Administrative Science Quarterly Vol.38: 20-50.

Hitt, Michael A., B.W. Keats and S.N. DeMarie. 1998. "Navigating in the New Competitive Landscape: Building Strategic Flexibility and Competitive Advantage in the $21^{\text {st }}$ Century." Academy of Management Executive Vol.12(4): 22-42.

Howell, Jane M. and C.A. Higgins. 1990. "Champions of Change: Identifying, Understanding, and Supporting Champions of Technological Innovations." Organizational Dynamics Vol.19: 4055 .

Huff, James O. and W.A.V. Clark. 1978. "Cumulative Stress and Cumulative Inertia: A Behavioral Model of the Decision to Move." Environment and Planning A. Vol.10: 1101-1119.

Huff, James O., A.S. Huff and H. Thomas. 1992. "Strategic Renewal and the Interaction of Cumulative Stress and Inertia." Strategic Management Journal Vol.13: 55-75.

Huff, Anne S., J.O. Huff and H. Thomas. 1994. "The Dynamics of Strategic Change." In: Herman Daems and H. Thomas (Eds.) Strategic Groups, Strategic Moves and Performance. Oxford UK: Elsevier Science: 31-62.

Hutt, Michael D., P.H. Reingen and J.R. Ronchetto Jr. 1988. "Tracing Emergent Processes in Marketing Strategy Formation.” Journal of Marketing. Vol.52 (January): 4-19.

Johanson, Jan and J.-E. Vahlne. 1990. "The Mechanism of Internationalization." International Marketing Review Vol.7(4): 11-24.

Johanson, Jan-Erik and F. Wiedersheim-Paul 1975. "The Internationalization Process of the Firm Four Swedish Case Studies.” Journal of Management Studies (October): 305-322.

Johnson, Gerry. 1988. "Rethinking Incrementalism.” Strategic Management Journal Vol.9: 75-91. 
Kvale, Steinar. 1996. InterViews An Introduction to Qualitative Research Interviewing. Thousand Oaks, CA: Sage Publications.

Kutschker, Michael, I. Bäurle and S. Schmid. 1997. International Evolution, International Episodes, and International Epochs - Implications for Managing Internationalization. Management International Review, 37(2) (Special Issue): 101-24.

Kuwada, Kotaro. 1998. "Strategic Learning: The Continuous Side of Discontinuous Strategic Change." Organization Science Vol.9(6): 719-736.

Lamb, Peter, and P. Liesch. 2002. "The Internationalization Process of the Smaller Firm: Re-Framing the Relationships between Market Commitment, Knowledge and Involvement." Management International Review. Forthcoming.

March, James G. 1991. "Exploration and Exploitation in Organizational Learning." Organization Science Vol.2(1): 71-87.

Melin, Leif. 1992. "Internationalization as a Strategy Process." Strategic Management Journal Vol.13: 99-118.

Miles, Matthew B., and A.M. Huberman. 1994. Qualitative Data Analysis. Second Edition. Thousand Oaks, CA: Sage Publications.

Narayanan, V.K. and L. Fahey. 1982. "The Micro-Politics of Strategy Formulation." Academy of Management Review Vol.7(1): 25-34.

Nelson, Richard R. and S.G. Winter. 1982. An Evolutionary Theory of Economic Change. The Belknap Press of Harvard University Press: Cambridge, MA.

Ocasio, William. 1995. "The Enactment of Economic Adversity: A Reconciliation of Theories of Failure-Induced Change and Threat-Rigidity." Research in Organizational Behavior Vol.17: 287-331.

Perlmutter, Howard V. 1969. "The Tortuous Evolution of the Multinational Corporation." Columbia Journal of World Business Vol.9 (January-February): 9-18.

Pettigrew, Andrew M. 1992. "The Character and Significance of Strategy Process Research.” Strategic Management Journal. Vol.13: 5-16.

Reed, Richard, and R.J. DeFillipi. 1990. "Causal Ambiguity, Barriers to Imitation, and Sustainable Competitive Advantage." Academy of Management Review Vol.15(1): 88-102.

Richards, Thomas J. and L. Richards. 1998. "Using Computers in Qualitative Research.” In: Norman K. Denzin and Y.S. Lincoln (Eds.) Collecting and Interpreting Qualitative Materials. Sage Publications: Thousand Oaks: 211-245.

Ross, Jerry and B.M. Staw. 1993. "Organizational Escalation and Exit: Lessons from the Shoreham Nuclear Power Plant." Academy of Management Journal Vol.36(4): 701-732.

Sage Publications. 1997. QSR NUD IST Rev 4. Thousand Oaks, CA: Sage Publications.

Schwenk, Charles R. 1989. "Linking Cognitive, Organizational and Political Factors in Explaining Strategic Change." Journal of Management Studies Vol.26(2): 177-187. 
Simonson, Itamar and B.M. Staw. 1992. "Deescalation Strategies: A Comparison of Techniques for Reducing Commitment to Losing Courses of Action." Journal of Applied Psychology Vol.77(4): 419-426.

Staw, Barry M., L.E. Sandelands, and J.E. Dutton. 1981. "Threat-Rigidity Effects in Organizational Behavior: A Multilevel Analysis.” Administrative Science Quarterly Vol.26: 501-524.

Tushman, Michael L. and E. Romanelli. 1985. "Organizational Evolution: A Metamorphosis Model of Convergence and Reorientation." Research in Organizational Behavior Vol.7: 171-222.

Tushman, Michael L., W.H. Newman and E. Romanelli. 1986. "Convergence and Upheaval: Managing the Unsteady Pace of Organizational Evolution." California Management Review Vol.29(1): 29-44.

Welch, Lawrence S. and R. Luostarinen. 1988. "Internationalization: Evolution of a Concept." Journal of General Management Vol.14(2): 34-55.

Welch, Lawrence S. and F. Wiedersheim-Paul. 1980. "Initial Exports - A Marketing Failure?” The Journal of Management Studies (October): 333-344.

Yin, Robert K. 1994. Case Study Research Design and Methods. Second Edition, Thousand Oaks, CA: Sage Publications. 


\begin{tabular}{|c|c|c|c|c|c|c|c|c|}
\hline Company & \multicolumn{2}{|l|}{ Kappa } & \multicolumn{2}{|c|}{ Eta } & \multicolumn{2}{|c|}{ Lambda } & \multicolumn{2}{|c|}{ Sigma } \\
\hline $\begin{array}{l}\text { Business } \\
\text { Activity }\end{array}$ & \multicolumn{2}{|c|}{$\begin{array}{l}\text { Trading of second hand } \\
\text { trucks and parts }\end{array}$} & \multicolumn{2}{|c|}{$\begin{array}{l}\text { Photographic and } \\
\text { imaging industry }\end{array}$} & \multicolumn{2}{|c|}{$\begin{array}{l}\text { Telecommunication } \\
\text { systems and equipment }\end{array}$} & \multicolumn{2}{|c|}{$\begin{array}{l}\text { Industrial engineering, } \\
\text { processing and } \\
\text { contracting }\end{array}$} \\
\hline $\begin{array}{l}\text { Stage in the } \\
\text { EPRG-Model }\end{array}$ & \multicolumn{2}{|c|}{$\begin{array}{l}\text { Ethnocentric -> } \\
\text { Regional }\end{array}$} & \multicolumn{2}{|c|}{$\begin{array}{l}\text { Geocentric } \leftrightarrow \\
\text { Ethnocentric -> } \\
\text { Regiocentric }\end{array}$} & \multicolumn{2}{|l|}{ Geocentric } & \multicolumn{2}{|c|}{$\begin{array}{l}\text { Ethnocentric -> } \\
\text { Regiocentric }\end{array}$} \\
\hline $\begin{array}{l}\text { Annual } \\
\text { Group } \\
\text { Turnover } \\
\text { (1999) } \\
\end{array}$ & \multicolumn{2}{|c|}{ \$ 131 million $(1997)$} & \multicolumn{2}{|c|}{$\$ 4.3$ billion } & \multicolumn{2}{|c|}{$\$ 22.3$ billion } & \multicolumn{2}{|c|}{$\$ 2.4$ billion } \\
\hline $\begin{array}{l}\text { International/ } \\
\text { Total Sales } \\
\text { Ratio }\end{array}$ & \multicolumn{2}{|l|}{$90 \%$} & \multicolumn{2}{|l|}{$85 \%$} & \multicolumn{2}{|l|}{$83 \%$} & \multicolumn{2}{|l|}{$65 \%$} \\
\hline Case & Spain & Belgium & Japan & Germany & Turkey & Russia & Brunei & UK \\
\hline $\begin{array}{l}\text { Strategic } \\
\text { Importance of } \\
\text { this Market }\end{array}$ & $\begin{array}{l}\text { Medium -> } \\
\text { High }\end{array}$ & High $->$ Low & $\begin{array}{l}\text { High }-> \\
\text { moderate }\end{array}$ & High & Medium & High & Low & High $->$ Low \\
\hline $\begin{array}{l}\text { Profitability } \\
\text { of this } \\
\text { Venture }\end{array}$ & $\begin{array}{l}\text { High -> } \\
\text { losses }\end{array}$ & $\begin{array}{l}\text { Medium -> } \\
\text { losses }\end{array}$ & Losses & High & $\begin{array}{l}\text { Medium -> } \\
\text { Low }\end{array}$ & $\begin{array}{l}\text { High -> } \\
\text { Losses }\end{array}$ & $\begin{array}{l}\text { High -> } \\
\text { Medium }\end{array}$ & \begin{tabular}{|l|} 
High -> \\
Losses
\end{tabular} \\
\hline $\begin{array}{l}\text { Number of } \\
\text { Years in the } \\
\text { Market }\end{array}$ & $\begin{array}{l}1980-1990 \\
10 \text { years }\end{array}$ & $\begin{array}{l}1977-1996 \\
19 \text { years }\end{array}$ & $\begin{array}{l}1973-1998 \\
25 \text { years }\end{array}$ & $\begin{array}{l}?-1998 \\
>20 \text { years }\end{array}$ & $\begin{array}{l}1983-1995 \\
12 \text { years }\end{array}$ & $\begin{array}{l}1983-1998 \\
15 \text { years }\end{array}$ & $\begin{array}{l}1985-1995 \\
10 \text { years }\end{array}$ & $\begin{array}{l}>1970-1999 \\
>30 \text { years }\end{array}$ \\
\hline
\end{tabular}

TABLE 1. Eight cases of international market withdrawal 


\begin{tabular}{lll}
\hline Type of Reaction & Explanation & Cases \\
\hline 1. Passive rejection & $\begin{array}{l}\text { A challenging coalition of middle managers rejects the } \\
\text { current tacticalal measures. However, no alternative } \\
\text { solution is proposed. }\end{array}$ & $\begin{array}{l}\text { Kappa-Belgium } \\
\text { Sigma-UK }\end{array}$ \\
\hline 2. Pro-active rejection & $\begin{array}{l}\text { A challenging coalition rejects the current tacticalal } \\
\text { measures. Moreover, it initiates the development of and } \\
\text { experimentation with a strategic alternative. }\end{array}$ & $\begin{array}{l}\text { Eta-Japan } \\
\text { Lambda-Russia } \\
\text { Kappa-Spain } \\
\text { Lambda-Turkey }\end{array}$ \\
\hline
\end{tabular}

TABLE 2. Two types of reaction of the challenging coalition 


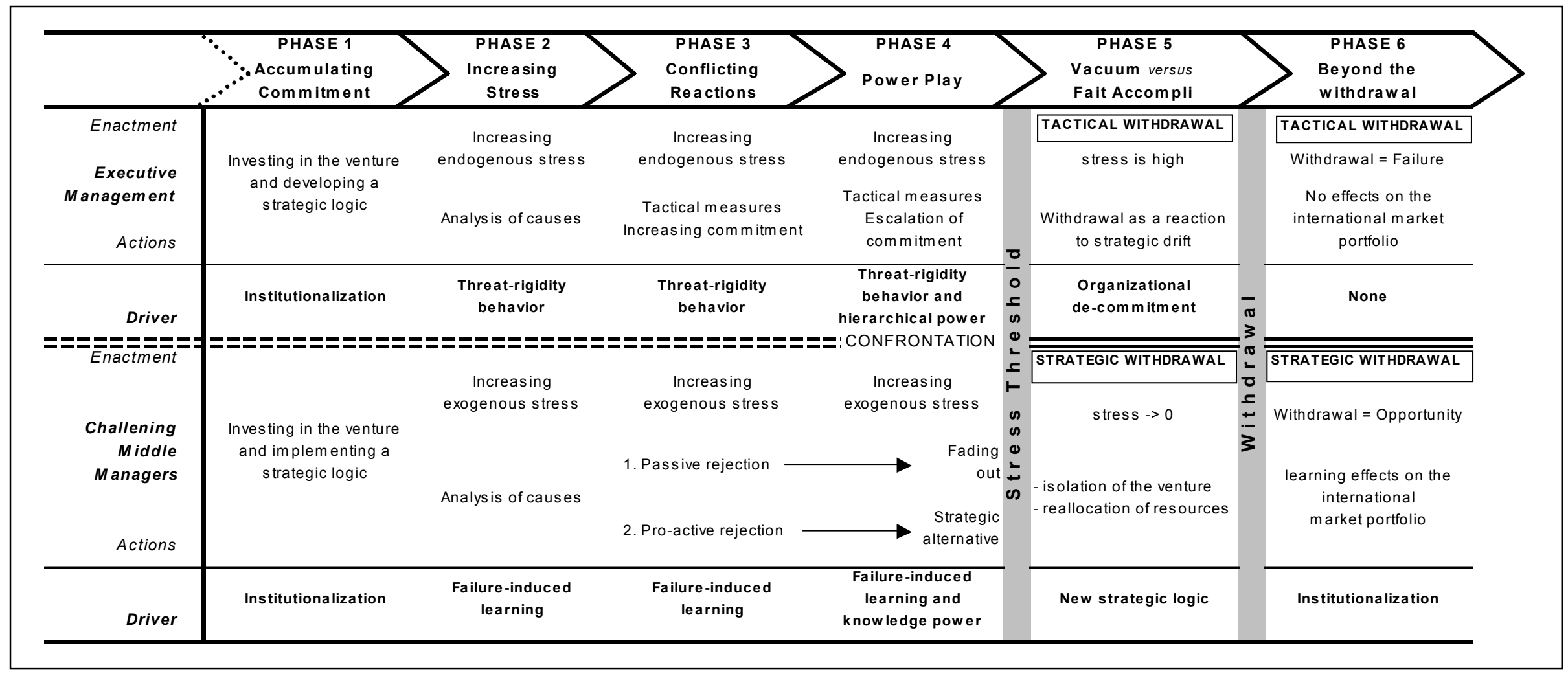

\section{FIGURE 1: A process model of international market withdrawal}

